Article

\title{
Examining Values, Virtues, and Tradition in the Republic of Tuva with Free-List and Demographic Data
}

\author{
Benjamin G. Purzycki, Theiss Bendixen \\ Aarhus University, Denmark
}

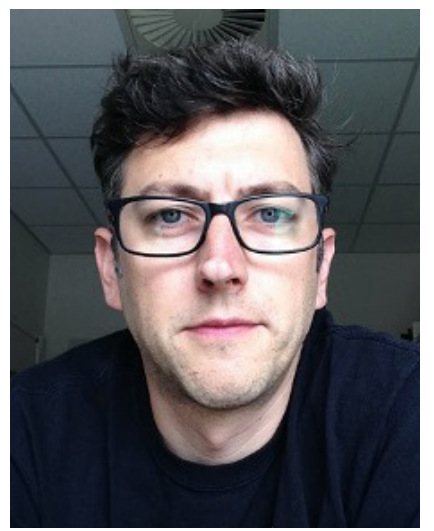

This article illustrates how using qualitative and quantitative social scientific methods together can help us examine sociocultural phenomena in precise, informative, and potentially useful ways. Using freely listed ethnographic data about what qualities Tuvans associate with "good" and "bad" Tuvan people, we examine general cultural patterns of Tuvan virtues. The data was collected in Tuva in 2009-2010 by interviewing nearly 100 Tuvans in Kyzyl and Western Tuva.

We also explore within-group contrasts by applying standard modeling techniques to this ethnographic data, finding demographic associations with listing specific items and those items' salience.

We conclude with a discussion of the promise and limitations of these methods.

Keywords: ethnography; Tuva; Tyva; Republic of Tuva; Tuvans; qualitative methods; quantitative methods; morality; virtues

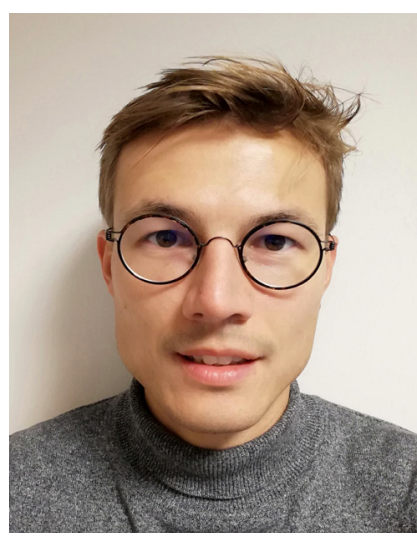

For citation:

Purzycki B. G. and Bendixen T. Examining Values, Virtues, and Tradition in the Republic of Tuva with Free-List and Demographic Data. New Research of Tuva, 2020, no. 4, pp. 6-18. DOI: https://www.doi.org/10.25178/nit.2020.4.1

PURZYCKI, Benjamin Grant, Ph.D., Associate Professor, Department of the Study of Religion, Aarhus University. Postal address: Jens Chr. Skous Vej 3, Building 1451, Room 525, 8000 Aarhus C, Denmark. Email: bgpurzycki@cas.au.dk BENDIXEN, Theiss, PhD Candidate, Department of the Study of Religion, Aarhus University. Postal address: Jens Chr. Skous Vej 3, Building 1451, Room 519, 8000 Aarhus C, Denmark. Email: tb@cas.au.dk

Пуржицки Бенджамин Грант - доктор наук (Ph.D.), доцент кафедры религиоведения Орхусского университета (Дания). Адрес: Jens Chr. Skous Vej 3, Building 1451, Room 525, 8000 Aarhus C, Denmark. Эл. адрес: bgpurzycki@cas.au.dk

Бендиксен Теисс - докторант кафедры религиоведения Орхусского университета (Дания). Адрес: Jens Chr. Skous Vej 3, Building 1451, Room 525, 8000 Aarhus C, Denmark. Эл. адрес: tb@cas.au.dk 


\title{
Изучение ценностей, добродетелей и традиций в Республике Тыва с помощью свободного списка и демографических данных
}

\author{
Бенджамин Г. Пуржищки, Теисс Бендиксен \\ Орхусский Университет, Дания
}

\begin{abstract}
Эта статья показывает на примерах, как качественные и количественные методов социологии, используемые в совокупности, помогают точно, информативно и продуктивно исследовать социокультурные явления.

Данные собраны в Туве в 2009-2010 г2. Были опрошены почти 100 человек - тувинцев - по Кызылу и в Западной Туве. Респонденты составляли свободный список качеств, которые они ассоциировали с тем, что значит быть «хорошим» и «плохим». Используя эти данные, авторы исследовали общие культурные образцы тувинских добродетелей.

Также в статье рассмотрены внутригрупповые контрасты. Для этого к этнографическим данным применялись стандартные методы моделирования, отмечались демографические ассоциации с перечислением конкретных предметов и их значимости.

В заключение авторы обсуждают перспективы и ограничения этих методов.
\end{abstract}

Ключевые слова: этнография; Тува; Тыва; Республика Тыва; тувинцы; качественные методы; количественные методы; нравственность; добродетель

Purzycki B. G., Bendixen T. Examining Values, Virtues, and Tradition in the Republic of Tuva with Free-List and Demographic Data // Новые исследования Тувы. 2020. № 4. C. 6-18. DOI: https://www.doi.org/10.25178/nit.2020.4.1

\section{Introduction}

In addition to offering relatively clear if narrow glimpses of social life, methods that embrace the systematic collection of both qualitative and quantitative data have the potential to inform strategies to address pressing social issues that communities face. Relying on only a few key informants, anecdotes, or limiting studies exclusively to qualitative or quantitative data collection runs the risk of creating false generalizations or over-simplifying our sense of social reality (Bernard, 2017; Handwerker, 2001). To the extent that it can be a catalyst of change, identifying particular patterns in this fashion can also contribute to cultural revitalization. In the context of applied social science, relying on anecdotes or cherry-picked examples may only stifle progress.

In the Republic of Tuva, a region that is currently enjoying a sociocultural renaissance with an increasing ethnic majority (Tarbastaeva, 2019), such techniques might be not only valuable for learning about traditions and how they are changing, but also important for addressing areas that need attention, such as health and welfare.

In this article, we: 1 ) introduce a package of methods that facilitate the analysis of cultural data; 2) provide an application of this package that Tuvan readers might find intuitive; 3) point to ways researchers can use such methods to use in their own studies; and 4) provide data and code for free, open-source analysis for reproduction and further use. The structure of the article is as follows. First, we introduce the method of freelisting, followed by a brief description of the study context and data. Then, we focus on incorporating this free-list interview data into a predictive statistical framework to examine relationships between the content of individuals' values and features of their demographic status. We conclude with a discussion of limitations and the promise such methods hold for future researchers. 
The data we assess here comes from projects carried out by Purzycki and his field assistants over multiple trips between the summer of 2009 and autumn of 2010. This team interviewed nearly 100 individuals around Kyzyl and western Tuva using a variety of survey-based interview instruments. In addition to demographics, the data we analyze here are free-list tasks asking residents to list what it means to be good and bad.

\section{Free-Listing and Cultural Salience}

The free-list method (Smith, Borgatti, 1997) is a simple technique that asks individuals to list items related to some domain (i. e., a class of related representations, ideas, and postulates). The method typically takes the following form: "Please list every X you can think of" but researchers can also cap the number of items people list (e. g., "Please list up to 10 things you think of when you think of Y"). As discussed below, it is important that the researcher records listed items in the exact order in which participants listed them. Once the researcher has conducted free-lists among a targeted sample size, he or she can then analyze the data and examine group-level properties of the listed items. If we operationalize "culture" to mean socially transmitted information that is stored in human minds (see Boyd, Richerson, 1985; D'Andrade, 1981; Sperber, 1996), the technique is maximally useful for getting a better understanding of any cultural domain of interest inasmuch as it is socially transmitted knowledge stored in human memory systems.

Researchers have used free-list methods in a wide variety of contexts and projects. Recent examples range from detailing knowledge of wild mushrooms in Yunnan, China (Brown, 2019) and mapping cultural models of food webs on coastal British Columbia (Levine et al., 2015) to assess the knowledge of ritual postures in Mauritius (Kundtová Klocová, 2017) and examining salient types of meat in Nigeria (Friant et al., 2019).

In Tuva specifically, Purzycki has used the free-list method to measure what spirit-masters (чер ээлери; cher eeleri) care about ${ }^{1}$, what Tuvans think constitutes a "good" and "bad" person (Purzycki, 2011; Purzycki et al., 2018), what Buddha Burgan cares about, and what gods and spirits Tuvans think are locally important (Purzycki, Holland, 2019; Purzycki, Kulundary, 2018).

Again, this method requires that participants freely list items they associated with the target domain. As noted above, keeping track of the order in which people list items is crucial; based on its listed order, each item gets its own salience score. To calculate this, simply subtract an item's order number, $k_{i}$, from 1 plus the total number of items a participant listed, $n$, then divide this by the total number of items the participant lists:

$$
s_{i}=\frac{n+1-k_{i}}{n}
$$

To illustrate, let's say that we ask some Tuvan participants to list the first ten animals that came to mind. After we collect our data, we enter it into a spreadsheet like the one illustrated in Table 1.

If someone, for example, lists sarlyk (yak) as the third item in a list of 10, sarlyk gets an item salience score of $0.8: s_{i}=\frac{10+1-3}{10}=0.8$

This way, all items listed first get an item salience of $1: s_{i}=\frac{n+1-1}{n}=1$.

The method assumes that items' listed order corresponds to their accessibility, and thus constitute a form of cognitive salience. As we demonstrate below, these salience scores are useful item- or individual-level data; whether or not an individual lists specific items and how salient those items are both tell us something about how and what an individual thinks about specific topic. But what about populations? That is, how can we use this method to examine what communities think?

\footnotetext{
1 Notably, Purzycki's earliest work in Tuva (Purzycki, 2010) relied on a very narrow set of informants' views, elicited exclusively in open-ended qualitative interviews. One of his interviewees claimed that cher eeleri "don't care about litter, they don't care about how you behave other than paying attention to them by 'feeding' them. Otherwise they get angry" (32) and this contributed to Purzycki's tentative generalization about Tuvan beliefs. However, a subsequent analysis of free-list data from a broader sample shows that the most salient item listed of what angers cher eeleri is pollution and destruction of the natural environment (Purzycki, 2011). This illustrates just how risky relying on a small number of informants can be.
} 
Table 1. Example spreadsheet of two individuals in hypothetical Tuvan sample free-listing animals.

Табл.1. Пример таблицы со свободным списком животных, гипотетически названных двумя тувинцами.

\begin{tabular}{|c|c|c|c|}
\hline ID & Order & Item & $s_{i}$ \\
\hline TVA001 & 1 & хой (xoi; sheep) & 1.00 \\
\hline TVA001 & 2 & өшкү (öshkü; goat) & 0.67 \\
\hline TVA001 & 3 & сарлык (sarlyk; yak) & 0.33 \\
\hline TVA002 & 1 & өшкү (öshkü; goat) & 1.00 \\
\hline TVA002 & 2 & хой (xoi; sheep) & 0.83 \\
\hline TVA002 & 3 & инек (inek; cow) & 0.67 \\
\hline TVA002 & 4 & теве (teve; camel) & 0.50 \\
\hline TVA002 & 5 & дуруяа (duruyaa; crane) & 0.33 \\
\hline TVA002 & 6 & сарлык (sarlyk; yak) & 0.17 \\
\hline
\end{tabular}

ID refers to unique participant number, $s_{i}$ refers to value from equation 1.

Calculating the cultural salience of a concept, $S$, requires taking the sum of all specific items' salience scores and dividing that by the total number of participants who completed the task, $N$ :

$$
S=\frac{\sum \frac{\left(n+1-k_{i}\right)}{n}}{N}=\frac{\Sigma s_{i}}{N}
$$

So, if 100 people listed ten animals each and we wanted to examine the cultural salience of sarlyk, we would first calculate the item salience, $s_{i}$, of sarlyk from equation 1 . Then, in accordance with equation 2 , we add up all of the $s_{i}$ scores for sarlyk, then divide this sum by 100. So, if all of the sarlyk $s_{i}$ scores summed to 73.16 , $S$ of $\operatorname{sarlyk}=0.7316$. If the sum of item salience, $\Sigma \frac{(n+1-k)}{n}$, for inek (cow) was 20.52 in a sample of 100 , $S_{\text {inek }}=0.21$.

If the two people in Table 1 were the only two people out of a sample of 100 who listed xoi (sheep), then $S_{x o i}=0.0183$.

This simple metric encapsulates cognitive salience by capturing a facet of salience within minds, but also cultural salience insofar as it incorporates the salience of items across minds. Indeed, Sincreases as a function of item ubiquity and placement; the earlier individuals list specific items, the more prevalent they typically are in the sample. As such, $S$ is a group-level trait that retains its individual-level components. We can compare such pools of shared information - cultural models - across groups to examine cultural variation (see, for example, Purzycki et al., 2018), but as we show below, since we retain individual-level components of cultural models, we can also assess within-group variation as well. We use this method to take a closer look at Tuvans' conceptions of what makes a "good" or "bad" Tuvan person.

\section{Study}

Methods

The data we analyze here was collected as part of a larger set of studies conducted between 2009 and 2010 (Purzycki, 2012). These studies were primarily about traditional Tuvan beliefs and practices, with particular emphasis on оvаа (оваалар; ritual cairns), cher eeleri, the spirit-masters of various places, and cooperation. In addition to basic demographic information and various questions about beliefs and practices, the following free-list questions were also included:

Кандыг шынарлар мөзүлуг, эки Тыва кижини тургузуп турар? Мөзүлүг, эки Тыва кижини тургузуп турар 5-10 шынардан адап көрүңер. Тодаргай болурун кызыдыңар.

Кандыг шынарлар мөзу-шынары багай Тыва кижини тургузуп турарыл? Мөзу-шынары багай Тыва кижини тургузуп турар 5-10 шынарданадаңар. Тодаргай болурун кызыдыңар.
[What things make a good Tuvan? Please list 5-10 things that you think makes a good Tuvan person. Please be specific.]

[What things make a bad Tuvan? Please list 5-10 things that you think makes a bad Tuvan person. Please be specific.] 
Purzycki compiled this data, translated items into English with the help of assistants, and entered the data into a spreadsheet. Then, he cleaned and recoded the data so that similar items were analyzed together (e. g., "drunk" and "too much alcohol" were turned into "alcohol"). Purzycki and Bendixen subsequently worked together to further clean and code the data. Note, however, that we coded the data at a relatively high resolution, so, for example, "drugs" and "smoking" are coded as different item types.

We analyzed all data in $\mathrm{R}^{1}$ with the AnthroTools package (Purzycki, Jamieson-Lane, 2017) for the freelist data and we conducted our focal regression with the rethinking package ${ }^{2}$. The $\mathrm{R}$ code and all originally translated data and subsequent codings used herein can be obtained here: https://github.com/bgpurzycki/ Tyvan-Values

\section{Participants}

Purzycki and his local research team interviewed nearly 100 participants in Kyzyl and the rural areas of western Tuva. In Kyzyl, they recruited participants in schools and homes during the winter and summer months, and in clinics and on the street during the summer months to maximize the regional variation of participants. In the rural areas, they used chain sampling and interviewed families neighboring Purzycki's hosts. We recruited only ethnic Tuvans who could understand the Tuvan language well. All interviews were conducted in Tuvan.

Table 2 details the general descriptive demographic statistics of participants. Out of 95 individuals sampled in total, 56 were women (59\%). If we define the proportion of one's life lived in the city as an index of urbanity, we can see that the sample is split roughly between urban and rural individuals (Fig. 1) ${ }^{3}$. For the analyses below, we centered participant age at the mean $\left(\right.$ age $-M_{\text {age }}$ ) and urbanity (urbanity $-M_{\text {urbanity }}$ ) for ease of interpretation ${ }^{4}$.

Table 2. Descriptive statistics of demographic sample.

Табл. 2. Демографические характеристики респондентов.

\begin{tabular}{|l|c|c|c|c|c|c|}
\hline & $M$ & $S D$ & $\operatorname{med}$ & $\min$ & $\max$ & $n$ \\
\hline Age & 38.68 & 13.47 & 37 & 22 & 73 & 92 \\
\hline Number of children & 1.95 & 1.32 & 2 & 0 & 7 & 88 \\
\hline Years of formal education & 13.85 & 4.67 & 15 & 1 & 22 & 91 \\
\hline Years lived in a city* & 20.48 & 12.56 & 22 & 0 & 48 & 88 \\
\hline
\end{tabular}

The value of $n$ reflects how many individuals answered the question.

*Chadaan was not counted as "urban" in this calculation.

\section{Results}

\section{Tuvan models of virtue}

General cultural models of virtue

Participants listed an average of 5.29 items $(S D=2.02, \min =1, \max =14, n=86)$ for the "good" list, and 5.21 items $(S D=2.22, \min =1, \max =13, n=84)$ for the "bad" list. Figure 2 illustrates the most salient components in Tuvan models of virtue across both tasks. The most salient thing listed for what constitutes a

\footnotetext{
${ }^{1}$ R Core Team, 2020. R: A Language and Environment for Statistical Computing. R Foundation for Statistical Computing. Vienna, Austria. URL: https://www.R-project.org/

${ }^{2}$ McElreath, R. (2020) Rethinking: Statistical Rethinking Book Package. R package version 2.01.

${ }^{3}$ This variation nicely corresponds to the official Russian statistics of residency: in the 2017 census, Tuva had a total population of 318,000 people with 172,000 (54\%) urban residents and 146,500 rural residents. The official Russian statistics can be obtained here: http://www.gks.ru

${ }^{4}$ This way, we ensure that the intercept $(\alpha)$-the coefficient indicating the likelihood of a positive value of the dependent variable when all predictors are held at zero-reflects the chances a woman of average age, average urbanity, and average years of education of the sample lists alcohol in her "bad" list. In other words, if we did not do this, our intercept would indicate the chances a zero-year-old female with no urbanity or education lists "alcohol" in her free-lists.
} 
"good" Tuvan is hard-working $(S=0.31)$ followed by kind $(S=0.29)$ and helpful $(S=0.28)$, while "bad" Tuvans are associated primarily with alcohol use and abuse $(S=0.53)$, untrustworthiness $(S=0.44)$, and laziness $(S=$ 0.28 ). Recall that the values of salience are greater the more people list them and the earlier they appear in lists; the sooner people list them the more likely other people will list them as well. As such, these represent Tuvans' cultural models of good and bad people.

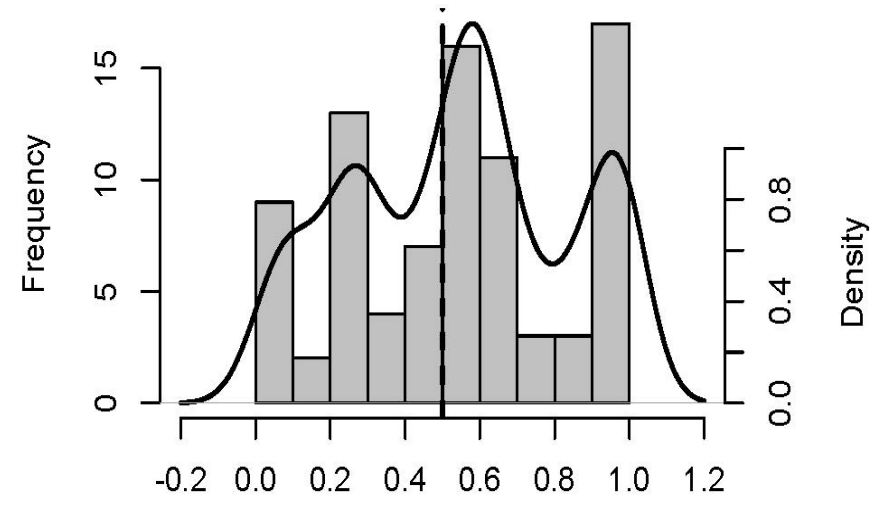

$\%$ of life spent living in urban environment
Figure 1. Histogram and density plot of sample's urbanity. Рис. 1. Гистограмма и плотность распределения степени урбанизации респондентов.

Dotted line is at the 50\% mark. Y-axis on left represents the frequency of values in the histogram,

$y$-axis on right indicates the density values of the line.

Out of the individuals considered in this graph $(n=84)$,

50 (60\%) spent more than half of their lives in an urban environment.

\section{Men's and women's cultural models of virtue}

Of course, the cultural models illustrated in Figure 2 mask any differences between groups of individuals in the sample. For example, as distinct traditional roles between men and women are explicit in many aphorisms and proverbs (Egorova, Kondakova, Kuzhuget, 2020), Tuvan men and women might have different conceptions of the good and bad. We can examine this question using the same methods but with one simple adjustment, namely, we use participant sex as a grouping variable. Here, then, we calculate two $S$ scores for each concept. We do this by summing the total $s_{i}$ scores of a concept for men and doing the same for women. Instead of dividing by the entire sample size, $N$, we divide the males' $s_{i}$ summations by the number of men and then perform the same for women. Figure 3 illustrates cultural models between men and women.
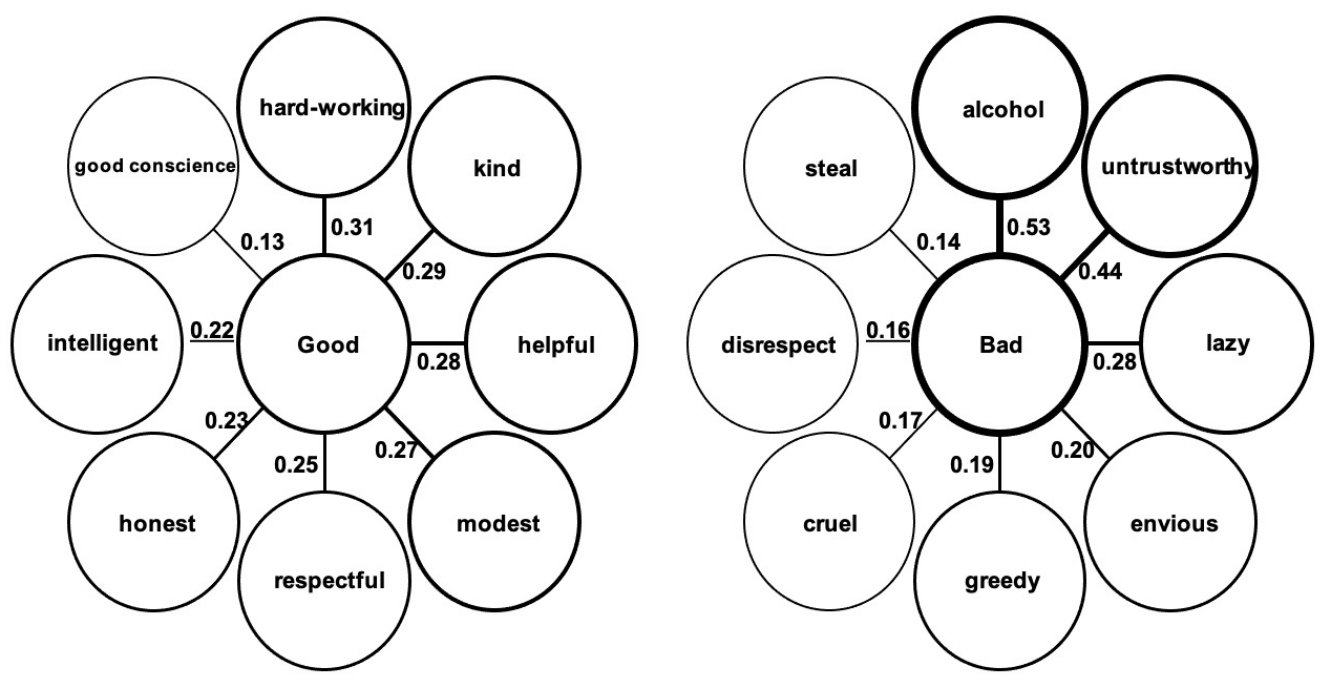

Figure 2. Flower plots of eight most salient concepts in Tuvans' models of good (left; $N=86$ ) and bad (right; $N=84$ ) Tuvans.

Рис. 2 Цветочная диаграмма восьми наиболее значимых концептов в моделях «хорошего тувинца» (слева, $N=86)$ u «плохого тувинца» (справа, $N=84)$. 
Some noticeable differences exist between the sexes. One immediate contrast reflects "kindness" being the mark of a good person: while being kind was the most salient thing women listed $(S=0.39)$, it was much lower for men $(S=0.14)$. On the other hand, the most salient item for men was "honesty" $(S=0.32)$ while this virtue has a salience score of only 0.18 for women. Recall from Figure 2 that among the general sample, hard work, kindness, and helpfulness were among the chief values. These common elements among the sexes appear different; when we look between the sexes, these items place lower on the models; when we look at betweengroup differences, we can see certain group-specific items increase or decrease in relative salience.
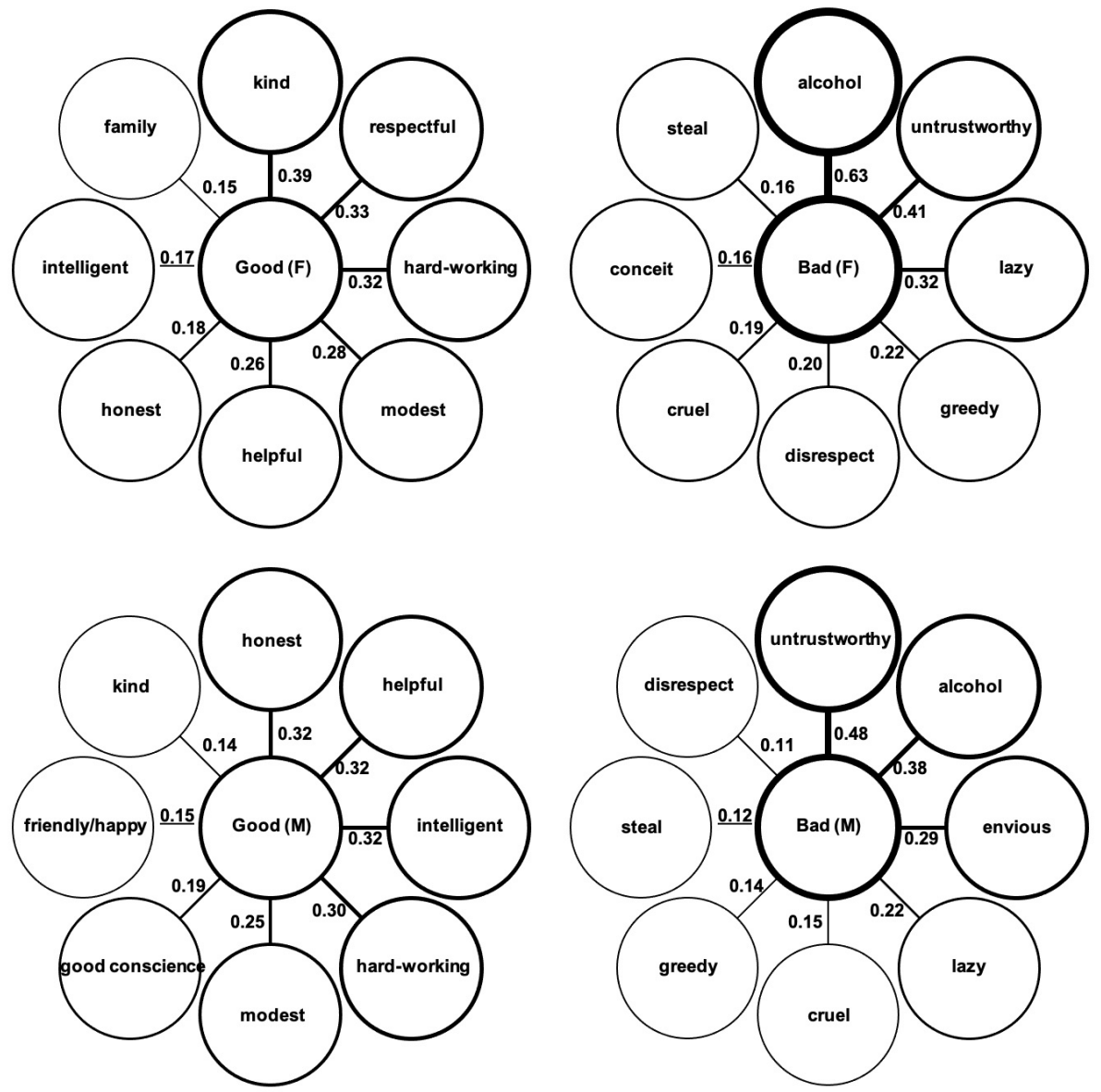

Figure 3. Flower plots of eight most salient concepts in Tuvans' models of good (left) and bad (right) across women (top) and men (bottom).

Рис. 3 Цветочная диаграмма восьми наиболее значимых концептов в моделях «хорошего человека» (левая колонка) $u$ «плохого человека» (правая) среди тувинских женщин (верхний ряд) и мужчин (нижний ряд).

Values indicate Smith's S. Topmost circles are most salient items, with decreasingly salient items in a clockwise fashion.

At a glance, there appears to be more consistency between the sexes in terms of what constitutes a bad Tuvan (see corresponding salience scores in Fig. 2). Alcohol use and abuse was the most salient item for women's conception of bad people $(S=0.63)$, followed by untrustworthiness $(S=0.41)$. Among males, these two items were also the top two listed: untrustworthiness had an $S$ of 0.48 while alcohol use was 0.38 . While these differences appear to be subtle, we can take a closer look and examine these between-group differences to determine if they are systematic differences.

Predicting associating alcohol with the "bad"

While salience might vary cross-culturally, many of the top free-listed items among Tuvans are consistent with data from a wider sample of populations from around the world (Purzycki et al., 2018). One especially 
devastating social problem common to indigenous communities is alcohol use and abuse. Correspondingly, many societies also view alcohol and other drugs as indicative of immoral behavior (Ibid.). As it has struggled with many problems associated with alcohol use, Tuva is no exception. Here, we examine this particular issue a little closer and ask the following questions: Who is more likely to list alcohol use as indicative of a «bad Tuvan»? Is urbanity associated with moralizing alcohol use? Are people with children more likely to list alcohol as "bad"? Are younger people less likely to? Are women more likely to moralize alcohol consumption?

To explore these questions, we merged the free-list data with participants' demographic data to assess the likelihood of listing "alcohol" using regression.

We formally defined our statistical model as follows:

$$
\begin{gathered}
y_{i} \sim \operatorname{Binomial}\left(1, p_{i}\right) \\
\operatorname{logit}\left(p_{i}\right)=\alpha+\beta * \operatorname{sex}_{i}+\omega * \operatorname{age}_{i}+\psi * \operatorname{urbanity}_{i}+\theta * \text { children }_{i} \\
\alpha \sim \operatorname{Normal}(0,10)_{1} \\
\beta, \omega, \psi, \theta \sim \operatorname{Normal}(0,1)
\end{gathered}
$$

Here, we model the presence of alcohol in individuals' free-lists, $y_{i}$ as probability $p_{i}$ on a binomial distribution (i.e., a logistic regression). We use a logit link function to fit a linear model with parameters for individual sex $(\beta)$, age $(\omega)$, urbanity $(\psi)$, and number of children $(\theta)$ as predictors, where individuals' ages and urban levels are centered at the sample mean. As we have no prior ideas or precedent studies about these relationships, we set our normally distributed parameter priors as weakly informative.

Table 3 reports the results.

Table 3. Regression results and 95\% credible intervals.

Табл. 3 Показатели регрессии и 95\% доверительные интервалы.

\begin{tabular}{|l|c|c|c|}
\hline & Estimate & Lower & Upper \\
\hline$\beta($ sex; male $=1)$ & -1.09 & -1.99 & -0.19 \\
\hline$\omega$ age $\left.^{*}\right)$ & 0.02 & -0.02 & 0.06 \\
\hline$\psi\left(\right.$ urbanity* $\left.^{*}\right)$ & 0.01 & -0.01 & 0.03 \\
\hline$\theta$ (children) & -0.05 & -0.46 & 0.35 \\
\hline$\alpha($ Intercept $)$ & 0.80 & -0.15 & 1.75 \\
\hline
\end{tabular}

*Values centered at sample mean.

Figure 4 presents the odds ratios of these estimates (exponentiated values) and their corresponding 95\% credible intervals. It shows that holding all other factors constant, the chances of listing alcohol are positive. The intercept ( $\alpha$; see footnote 4$)$-representing the likelihood that an average-aged female who has spent the average amount of time in an urban environment with no children lists "alcohol"-indicates a $69 \%$ chance of listing alcohol (the logistic transform of 0.80).

There is virtually no change in the likelihood of listing alcohol as urbanity, age, and number of children increase. In other words, older or urban participants are not any more or less likely to claim alcohol use is the mark of a bad Tuvan. As indicated by the relatively narrow width of their corresponding intervals, this lack of effect is precisely estimated whereas there is more uncertainty around the association with having children.

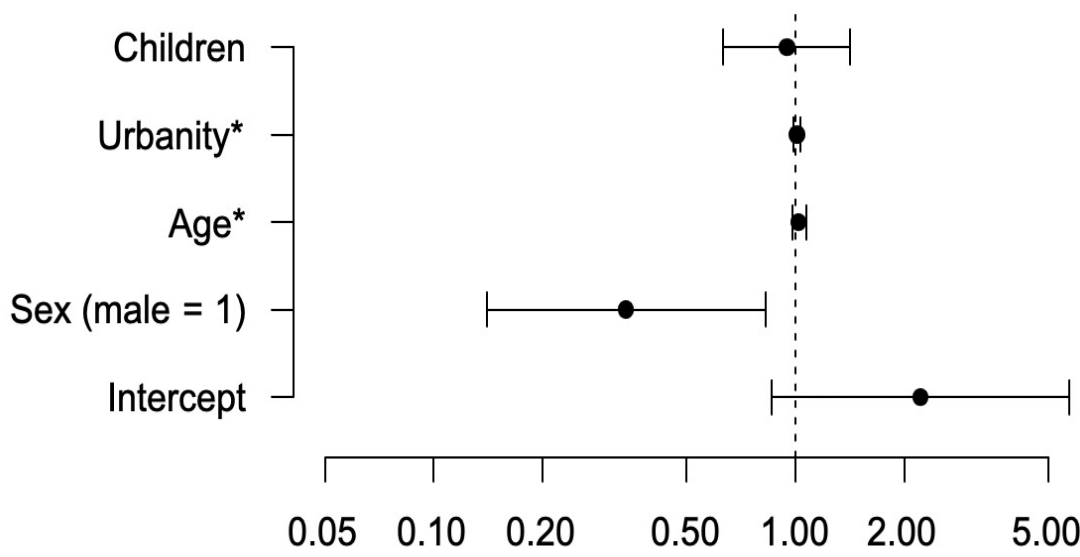

Figure 4. Odds ratio plot (exponentiated estimates from Table 3) of regression estimates and $95 \%$ credible intervals predicting listing alcohol in "bad" free-list task.

Рис. 4. График отношения шансов (потенцированные данные из

табл. 3) показателей регрессии и 95\% доверительных интервалов, прогнозирующих, будет ли указан алкоголь среди «плохих» черт в свободном списке. $X$-axis is on logarithmic scale. Dotted line is threshold of no effect; estimates to the right of line indicate positive association and those to 
However, being male dramatically decreases the chances of listing alcohol. A male of average age and urbanity with no children has a $43 \%$ chance of listing alcohol (the logistic transform of the intercept 0.80 plus the estimate for sex, -1.09). In other words, male Tuvans of average age and urbanity with no children are $26 \%$ less likely than women of similar status to list alcohol among the things that constitute bad Tuvans.

\section{Age, tradition, and values}

We also explored various items' salience and their relationship with participant age. As the republic has been undergoing a cultural revitalization of its traditions since the Soviet era, we reasoned that elder Tuvans might be more or less inclined to list - and list sooner or later - various concepts. Any substantive findings along these lines might be indicative of general age-specific values or genuine changes in values through time. As this is purely exploratory for the purposes of illustration, we cannot rule out one interpretation over the other. As such, these results should be treated with this caution in mind.

We first examined indicators of tradition maintenance; while recognizing the relationship is a complicated one, we wondered if such values might be less salient to younger Tuvans because of the rapidly changing cultural milieu in the republic (see, for example, Argue et al., 1999; Hayward, Krause, 2015; Shaver, Sosis, 2014, for investigations of commitment to religious traditions across age). Then again, because of the inculcation of Soviet values of "progress", older Tuvans might be less inclined to list values associated with traditions. Other plausible scenarios and interpretations undoubtedly abound.

To investigate these questions, we recoded some of the data to reflect corresponding values of national tradition. One version of our recoding lumps together "traditions" (e. g., "love for Tuvan people", "passing traditions on to children", "love of homeland") in a single code while leaving all other codes untouched. Another version combines these into a category that also includes indices of family (e. g., "love for family and parents", "listening to parents", "being faithful to one's spouse"). We then examined if there was any relationship between the item salience, $s_{i}$, of these codes and age.
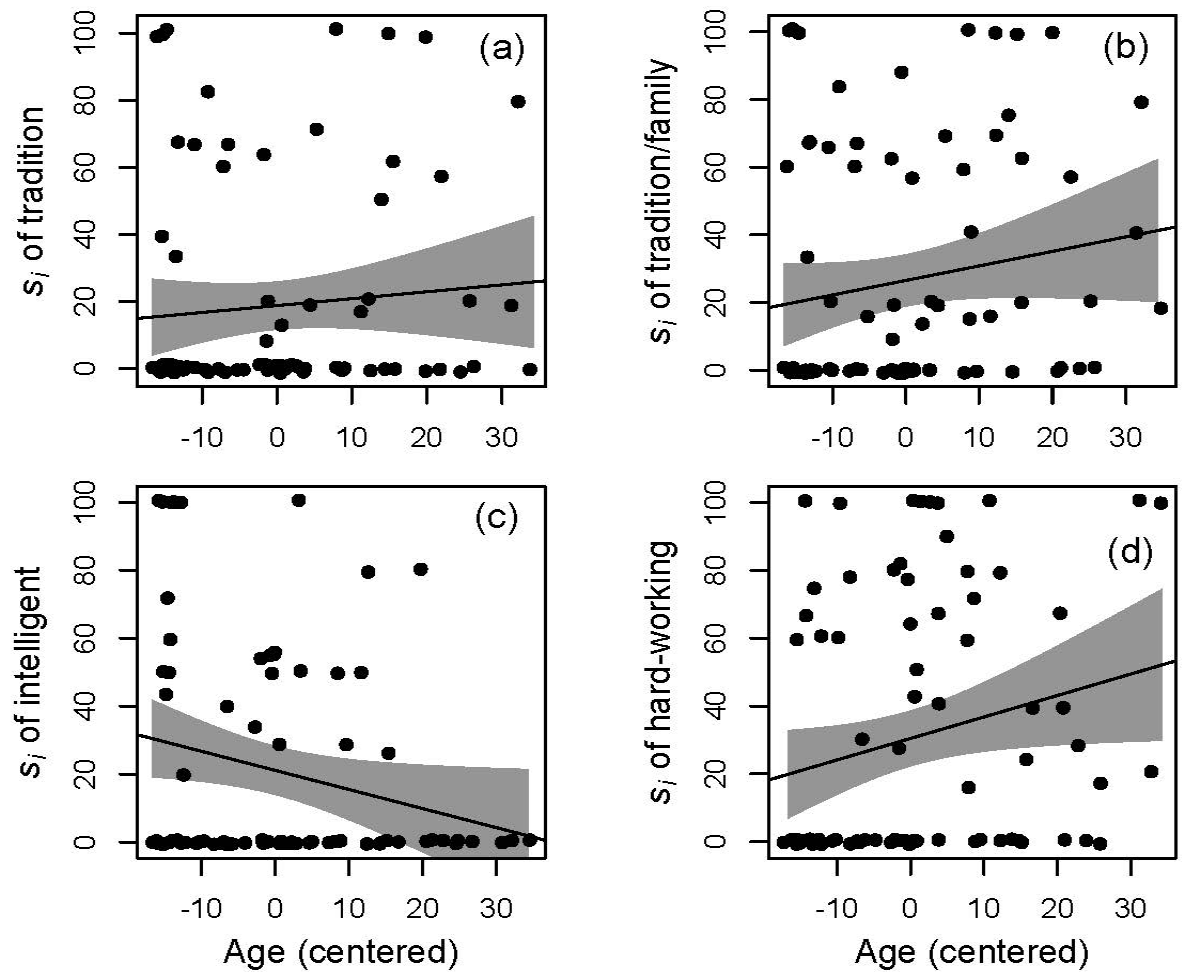

Figure 5. Correlation plots of mean-centered age and item salience $\left(s_{\text {. }}\right)$ of: (a) "tradition", (b) "tradition/family", (c) "intelligent", and (d) "hard-working".

Рис. 5. Поле корреляций среднего возраста и значимости концептов (a) “традиция”, (b) “традиция/семья”, (c) “интеллигентность” и (d) “трудолюбие” 
Figure 5 illustrates the correlations between age and item salience of "tradition" (a) and the combined tradition-family coding (b). The first thing to notice about these plots is that many participants simply did not list items that we coded as "tradition" or "tradition/family". Given all of these zeroes, simple linear regressions predict that someone at the sample average age is likely to have relatively low item salience scores of 0.19 $(95 \% \mathrm{CI}=[0.12,0.26])$ for tradition and $0.27(95 \%=[0.19,0.34])$ for tradition/family. Age has a positive-but very slight-relationship with listing "tradition" items $(\beta=0.21,95 \% \mathrm{CI}=[-0.33,0.74])$. It has a more obviousbut also unreliable - positive relationship with tradition/family, however $(\beta=0.43,95 \% \mathrm{CI}=[-0.14,1.00])$; it predicts that someone who is 30 years older than the sample average to have an $s_{i}$ of $0.39,0.12$ more than an average-aged person. In sum, then, while there are hints of a positive relationship between age and salience of traditional and family values, further inquiry is required to have more confidence in such patterns.

We also explored two other listed items that were salient enough between both sexes (Figure 3) to see if they had any association with age. Figure 5 illustrates the two we chose: "intelligent" (c) and "hard-working" (d). These plots show a general, but very slight negative trend for the item salience of "intelligence" ( $\alpha=$ $\left.21.10[13.95,28.25], \beta_{\text {age }}=-0.56[-1.09,-0.03]\right)$ while "hardworking" shows a steady, positive relationship ( $\alpha=$ $\left.30.44[22.30,38.59], \beta_{\text {age }}=0.63[0.03,1.24]\right)$. Could it be that younger Tuvans think of intelligence because of general shifts in values? Are younger Tuvans simply more likely to be closer to their studies and their values therefore reflect qualities that facilitate student success? Another curious age-related value is that older Tuvans appear to have considerably higher salience for "hard-working". There are few elderly outliers and a high concentration of younger individuals who simply did not list this value. Again, are these broad shifts in Tuvan values or the reflections of the value differences between the young and old? While further studies and data collection would rule out competing possibilities, we raise these questions simply to illustrate that these methods together point to value differences among Tuvans and identifying these differences raises more questions.

\section{Discussion}

In this report, we assessed individual and group-level values of Tuvans both descriptively - in the form of free-list data analysis - and predictively using regression. The free-list data shows that, among other things, central to the Tuvan conception of the "bad" is alcohol use and being untrustworthy while the mark of a "good" Tuvan is a good work ethic, being helpful, kind, and modest. By selecting one salient problem - alcohol use we examined how some aspects of Tuvan demography predict listing it; we demonstrated that even though alcohol use and abuse is the most salient notion in Tuvans' models, women are far more likely than men to list alcohol in their free-list data. However, age, urbanity, and number of children show no relationship.

Tuvans know the problems associated with alcohol use and abuse all too well. According to one source (Semyonova et al., 2014), in 2009, Tuvan males had the highest rates of fatal accidental alcohol poisoning for all Russian regions (74.6 per 100,000). The same source reports that Tuvan women were among the ten highest groups in Russia for alcohol-related mortality $(82.5$ per 100,000$)$. While alcohol-related problems deeply affect both men and women, women are significantly more likely to associate alcohol use with being a "bad" Tuvan. Why would this be the case? Are men more inclined to downplay the effects of alcohol because they are risk-prone? Various sources suggest that around the world, males typically start drinking at an earlier age, more often, and in greater quantities than females (e.g., see Hughes et al., 2016; May, Gossage, 2001; Rehm et al., 2003). On the other hand, the lack of a clear correlation between age and the likelihood of listing alcohol suggests that - at the time of data collection - there was little in the way of a generational shift in values; younger people showed no indication of associating alcohol as "bad" any more than their elders did.

As with any method and study, there are limitations to the present inquiry. For one, this method will not include every important cultural value. In Purzycki's experience, Tuvans justifiably pride themselves on their sense of hospitality; if you enter one's home, you are treated immediately to an abundance of food, comfort, and conversation. Note that while "kindness" and "respectful" were both at the top of the lists and are undoubtedly a part of Tuvan hospitality, the virtue itself was not explicitly listed as particularly salient. This, then, points to a discrepancy between the values that individuals might hold that characterize good and bad people, and the virtues they live by with respect to particular situations.

A similar issue with these methods is that free-lists are clearly not exhaustive. For example, most Tuvans undoubtedly think of violence and murder as "bad", but participants did not list these items that often. In one sense, this is surprising in light of the fact that between 1991 and 2005, Tuva had the highest homicide rate per capita of all Russian regions (Treyger, 2011). However, as drinking and violence are closely linked in 
Tuvan society, they might also be closely linked in Tuvans' minds; listing "alcohol” might indicate all manner of social ills caused by the excesses of drinking.

To address these and other issues, researchers could easily modify our approach-linking qualitative freelists and demographic data to focus on other questions or more targeted iterations of the ones we asked. For instance, instead of using demographics to predict free-list data, one could use free-list data to ask other things such as questions about behavior. For example, does framing alcohol as an immoral behavior reduce the chances that one drinks (for evidence suggesting that the perception of drinking norms is associated with drinking behavior, see Larimer et al., 2020)? Does listing "honesty" predict acting honestly (e. g., see Purzycki et al., 2018)? How does knowledge of traditional Tuvan practices vary across ages? Systematically asking such questions with precise methods can contribute to understanding how values evolve, but also has the potential to assess how we might go about contributing to their evolution in constructive, targeted ways.

\section{Acknowledgments}

We thank Xülerben Kadyg-ool for the invitation and encouragement to write this piece and all those who participated in the study. Purzycki would like to thank Xülerben Kadyg-ool, Brian and Chaizu Donahoe, Nadia Oorzhak, Sean and Sveta Quirk, Anai-Khaak and Zhenya Saryglar, Valentina Süzükei, Aldar Tamdyn, the students and staff at TIGI, and the Tuvan National Orchestra for their help and friendship. Grants awarded to Purzycki in 2009 by Oxford University's Cognition, Religion, and Theology Project and the University of Connecticut's Department of Anthropology financially supported this research. We also thank the Aarhus University Research Foundation for generous support and the editors of The New Research of Tuva for their feedback and management.

\section{REFERENCES}

Argue, A., Johnson, D. R. and White, L. K. (1999) Age and religiosity: Evidence from a three-wave panel analysis. Journal for the Scientific Study of Religion, no. 38, pp. 423-435. DOI: https://doi.org/10.2307/1387762

Bernard, H. R. (2017) Research Methods in Anthropology: Qualitative and Quantitative Approaches. $6^{\text {th }}$ ed. Lanham, Rowman \& Littlefield. 732 p.

Boyd, R. and Richerson, P. J. (1985) Culture and the Evolutionary Process. Chicago, University of Chicago Press. 331 p.

Brown, M. (2019) Yi ethnomycology: Wild mushroom knowledge and use in Yunnan, China. Journal of Ethnobiology, no. 39, pp. 131-157. DOI: https://doi.org/10.2993/0278-0771-39.1.131

D’Andrade, R. G. (1981) The cultural part of cognition. Cognitive Science, no. 5, pp. 179-195.DOI: https://doi.org/10.1207/ s15516709cog0503_1

Egorova, A. I., Kondakova, A. P. and Kuzhuget, M. A. (2020) Gendernye stereotipy v tyvinskikh poslovitsakh i pogovorkakh [Gender stereotypes in Tuvan proverbs and sayings]. New Research of Tuva, no. 1, pp 19-34. (In Russ.). DOI: https://doi.org/10.25178/nit.2020.1.2

Friant, S., Ayambem, W. A., Alobi, A. O., Ifebueme, N. M., Otukpa, O. M., Ogar, D. A., Alawa, C. B. I., Goldberg, T. L., Jacka, J. K. and Rothman, J. M. (2019) Life on the rainforest edge: Food security in the agricultural-forest frontier of Cross River State, Nigeria. Frontiers in Sustainable Food Systems, no. 3, p. 113. DOI: https://doi.org/10.3389/fsufs.2019.00113

Handwerker, P. W. (2001) Quick Ethnography: A Guide to Rapid Multi-Method Research. Lanham, Rowman Altamira. $312 \mathrm{p}$.

Hayward, R. D. and Krause, N. (2015) Aging, social developmental, and cultural factors in changing patterns of religious involvement over a 32-year period: An age-period-cohort analysis of 80 countries. Journal of Cross-Cultural Psychology, no. 46, pp. 979-995. DOI: https://doi.org/10.17759/chp.2015110109

Hughes, T. L., Wilsnack, S. C. and Kantor, L. W. (2016) The influence of gender and sexual orientation on alcohol use and alcohol-related problems: Toward a global perspective. Alcohol Research: Current Reviews, vol. 38, pp. $121-132$.

Kundtová Klocová, E. (2017) Body in Ritual Space: Communication through Embodied Practices in Religious Ritual. Brno, Masaryk University. Doctoral dissertation. 186 p.

Larimer, M. E., Parker, M., Lostutter, T., Rhew, I., Eakins, D., Lynch, A., Walter, T., Egashira, L., Kipp, B. J. and Duran, B. (2020) Perceived descriptive norms for alcohol use among tribal college students: Relation to self-reported alcohol use, consequences, and risk for alcohol use disorder. Addictive Behaviors, no. 102, pp. 106-158. DOI: http://doi.org/10.1016/j. addbeh.2019.106158 
Levine, J., Muthukrishna, M., Chan, K. M. and Satterfield, T. (2015) Theories of the deep: Combining salience and network analyses to produce mental model visualizations of a coastal British Columbia food web. Ecology and Society, no. 20, pp. 42-72. DOI: http://doi.org/10.5751/ES-08094-200442

May, P. A. and Gossage, J. P. (2001) New data on the epidemiology of adult drinking and substance use among American Indians of the northern states: male and female data on prevalence, patterns, and consequences. American Indian and Alaska Native Mental Health Research: The Journal of the National Center, no. 10, pp. 1-26. DOI: http://doi.org/10.5820/ aian.1002.2001.1

Purzycki, B. G. (2010) Spirit masters, ritual cairns, and the adaptive religious system in Tyva. Sibirica, no. 9, pp. 21-47. DOI: http://doi.org/10.3167/sib.2010.090202

Purzycki, B. G. (2011) Tyvan cher eezi and the socioecological constraints of supernatural agents' minds. Religion, Brain \& Behavior, no. 1, pp. 31-45. DOI: http://doi.org/10.1080/2153599X.2010.550723

Purzycki, B. G. (2012) Finding Minds in the Natural World: Dynamics of the Religious System in the Tyva Republic. Storrs, University of Connecticut. Doctoral dissertation. 505 p.

Purzycki, B. G. and Holland, E. C. (2019) Buddha as a god: An empirical assessment. Method \& Theory in the Study of Religion, no. 31, pp. 347-375. DOI: http://doi.org/10.1163/15700682-12341453

Purzycki, B. G. and Jamieson-Lane, A. (2017) AnthroTools: An R package for cross-cultural ethnographic data analysis. Cross-Cultural Research, no. 51, pp. 51-74. DOI: http://doi.org/10.1177/1069397116680352

Purzycki, B. G. and Kulundary, V. (2018) Buddhism, identity, and class: Fairness and favoritism in the Tyva Republic. Religion, Brain \& Behavior, no. 8, pp. 205-226. DOI: http://doi.org/10.1080/2153599X.2016.1267031

Purzycki, B. G., Pisor, A. C., Apicella, C., Atkinson, Q., Cohen, E., Henrich, J., McElreath, R., McNamara, R. A., Norenzayan, A., Willard, A. K. et al. (2018) The cognitive and cultural foundations of moral behavior. Evolution and Human Behavior, no. 39, pp. 490-501. DOI: http://doi.org/10.1016/j.evolhumbehav.2018.04.004

Rehm, J., Rehn, N., Room, R., Monteiro, M., Gmel, G., Jernigan, D. and Frick, U. (2003) The global distribution of average volume of alcohol consumption and patterns of drinking. European Addiction Research, no. 9, pp. 147-156. DOI: http://doi. org/10.1159/000072221

Semyonova, V. G., Gavrilova, N. S., Sabgayda, T. P., Antonova, O. M., Nikitina, S. Y. and Evdokushkina, G. N. (2014) Approaches to the Assessment of Alcohol-Related Losses in the Russian Population. In: Anson, J., Luy, M. (Eds.) Mortality in an International Perspective. New York, Springer International Publishing. 359 p. Pp. 137-168.

Shaver, J. H. and Sosis, R. (2014) How does male ritual behavior vary across the lifespan? Human Nature, no. 25, pp. 136-160. DOI: http://doi.org/10.1007/s12110-014-9191-6

Smith, J. J. and Borgatti, S. P. (1997) Salience counts-and so does accuracy: Correcting and updating a measure for free-list-item salience. Journal of Linguistic Anthropology, no. 7, pp. 208-209. DOI: http://doi.org/10.1525/jlin.1997.7.2.208

Sperber, D. (1996) Explaining Culture: A Naturalistic Approach. Malden, Blackwell. 176 p.

Tarbastaeva, I. S. (2019) Tuva's transformation into a monoethnic region: Risks and possibilities. Problems of Economic Transition, no. 61, pp. 54-68. DOI: http://doi.org/10.1080/10611991.2019.1691879

Treyger, E. A. (2011) The Soviet Roots of Post-Soviet Order. Cambridge, Harvard University. Doctoral dissertation.

Submission date: 20.06 .2020 .

\section{СПИСОК ЛИТЕРАТУРЫ}

Argue, A., Johnson, D. R. and White, L. K. (1999) Age and religiosity: Evidence from a three-wave panel analysis // Journal for the Scientific Study of Religion. № 38. P. 423-435. DOI: https://doi.org/10.2307/1387762

Bernard, H. R. (2017) Research Methods in Anthropology: Qualitative and Quantitative Approaches. $6^{\text {th }}$ ed. Lanham : Rowman \& Littlefield. 732 p.

Boyd, R., Richerson, P. J. (1985) Culture and the Evolutionary Process. Chicago : University of Chicago Press. 331 p.

Brown, M. (2019) Yi ethnomycology: Wild mushroom knowledge and use in Yunnan, China // Journal of Ethnobiology. № 39. P. 131-157. DOI: https://doi.org/10.2993/0278-0771-39.1.131

D’Andrade, R. G. (1981) The cultural part of cognition // Cognitive Science. № 5. P. 179-195. DOI: https://doi. org/10.1207/s15516709cog0503_1

Егорова, А. И., Кондакова, А. П., Кужугет, М. А. (2020) Гендерные стереотипы в тувинских пословицах и поговорках // Новые исследования Тувы. № 1. С. 19-34. DOI: https://doi.org/10.25178/nit.2020.1.2 
Friant, S., Ayambem, W. A., Alobi, A. O., Ifebueme, N. M., Otukpa, O. M., Ogar, D. A., Alawa, C. B. I., Goldberg, T. L., Jacka, J. K., Rothman, J. M. (2019) Life on the rainforest edge: Food security in the agricultural-forest frontier of Cross River State, Nigeria // Frontiers in Sustainable Food Systems. № 3. P. 113. DOI: https://doi.org/10.3389/fsufs.2019.00113

Handwerker, P. W. (2001) Quick Ethnography: A Guide to Rapid Multi-Method Research. Lanham : Rowman Altamira. $312 \mathrm{p}$.

Hayward, R. D., Krause, N. (2015) Aging, social developmental, and cultural factors in changing patterns of religious involvement over a 32-year period: An age-period-cohort analysis of 80 countries // Journal of Cross-Cultural Psychology. № 46. P. 979-995. DOI: https://doi.org/10.17759/chp.2015110109

Hughes, T. L., Wilsnack, S. C., Kantor, L. W. (2016) The influence of gender and sexual orientation on alcohol use and alcohol-related problems: Toward a global perspective // Alcohol Research: Current Reviews. Vol. 38. P. 121-132.

Kundtová Klocová, E. (2017) Body in Ritual Space: Communication through Embodied Practices in Religious Ritual. Brno, Masaryk University. Doctoral dissertation. 186 p.

Larimer, M. E., Parker, M., Lostutter, T., Rhew, I., Eakins, D., Lynch, A., Walter, T., Egashira, L., Kipp, B. J., Duran, B. (2020) Perceived descriptive norms for alcohol use among tribal college students: Relation to self-reported alcohol use, consequences, and risk for alcohol use disorder // Addictive Behaviors. № 102. P. 106-158. DOI: http://doi.org/10.1016/j. addbeh.2019.106158

Levine, J., Muthukrishna, M., Chan, K. M., Satterfield, T. (2015) Theories of the deep: Combining salience and network analyses to produce mental model visualizations of a coastal British Columbia food web // Ecology and Society. № 20 . P. 42-72. DOI: http://doi.org/10.5751/ES-08094-200442

May, P. A., Gossage, J. P. (2001) New data on the epidemiology of adult drinking and substance use among American Indians of the northern states: male and female data on prevalence, patterns, and consequences //American Indian and Alaska Native Mental Health Research: The Journal of the National Center. № 10. P. 1-26. DOI: http://doi.org/10.5820/ aian.1002.2001.1

Purzycki, B. G. (2010) Spirit masters, ritual cairns, and the adaptive religious system in Tyva // Sibirica. № 9. P. $21-47$. DOI: http://doi.org/10.3167/sib.2010.090202

Purzycki, B. G. (2011) Tyvan cher eezi and the socioecological constraints of supernatural agents' minds // Religion, Brain \& Behavior. № 1. P. 31-45. DOI: http://doi.org/10.1080/2153599X.2010.550723

Purzycki, B. G. (2012) Finding Minds in the Natural World: Dynamics of the Religious System in the Tyva Republic. Storrs, University of Connecticut. Doctoral dissertation. 505 p.

Purzycki, B. G. and Holland, E. C. (2019) Buddha as a god: An empirical assessment // Method \& Theory in the Study of Religion. № 31. P. 347-375. DOI: http://doi.org/10.1163/15700682-12341453

Purzycki, B. G., Jamieson-Lane, A. (2017) AnthroTools: An R package for cross-cultural ethnographic data analysis // Cross-Cultural Research. № 51. P. 51-74. DOI: http://doi.org/10.1177/1069397116680352

Purzycki, B. G., Kulundary, V. (2018) Buddhism, identity, and class: Fairness and favoritism in the Tyva Republic // Religion, Brain \& Behavior. № 8. P. 205-226. DOI: http://doi.org/10.1080/2153599X.2016.1267031

Purzycki, B. G., Pisor, A. C., Apicella, C., Atkinson, Q., Cohen, E., Henrich, J., McElreath, R., McNamara, R. A., Norenzayan, A., Willard, A. K. et al. (2018) The cognitive and cultural foundations of moral behavior // Evolution and Human Behavior. № 39. P. 490-501. DOI: http://doi.org/10.1016/j.evolhumbehav.2018.04.004

Rehm, J., Rehn, N., Room, R., Monteiro, M., Gmel, G., Jernigan, D., Frick, U. (2003) The global distribution of average volume of alcohol consumption and patterns of drinking // European Addiction Research. № 9. P. 147-156. DOI: http:// doi.org/10.1159/000072221

Semyonova, V. G., Gavrilova, N. S., Sabgayda, T. P., Antonova, O. M., Nikitina, S. Y., Evdokushkina, G. N. (2014) Approaches to the Assessment of Alcohol-Related Losses in the Russian Population // Anson, J., Luy, M. (Eds.), Mortality in an International Perspective. New York : Springer International Publishing. 359 p. P. 137-168.

Shaver, J. H. and Sosis, R. (2014) How does male ritual behavior vary across the lifespan? // Human Nature. № 25. P. 136-160. DOI: http://doi.org/10.1007/s12110-014-9191-6

Smith, J. J., Borgatti, S. P. (1997) Salience counts-and so does accuracy: Correcting and updating a measure for free-listitem salience // Journal of Linguistic Anthropology. № 7. P. 208-209. DOI: http://doi.org/10.1525/jlin.1997.7.2.208

Sperber, D. (1996) Explaining Culture: A Naturalistic Approach. Malden : Blackwell. 176 p.

Tarbastaeva, I. S. (2019) Tuva's transformation into a monoethnic region: Risks and possibilities // Problems of Economic Transition. № 61. P. 54-68. DOI: http://doi.org/10.1080/10611991.2019.1691879

Treyger, E. A. (2011) The Soviet Roots of Post-Soviet Order. Cambridge : Harvard University. Doctoral dissertation.

Дата поступления: 20.06.2020 